\title{
Marine Data Collection: US Perspectives
}

\author{
J. Ashley Roach ${ }^{1}$
}

Coastal State jurisdiction over foreign marine data collection activities depends on which type of activity is involved and on the maritime zone in which it is conducted. The 1982 United Nations Convention on the Law of the Sea ${ }^{2}$ (Los Convention) does not use the term "marine data collection" which is used in this article as a generic term without legal content, as the umbrella under which to consider the various data collection activities in the marine environment. $^{3}$

Under "marine data collection" the following five categories, with seven subcategories, are considered:

- Marine scientific research (MSR);

- Surveys

- Hydrographic surveys; and

- Military surveys;

- Operational oceanography

- Ocean state estimation;

- Weather forecasting; and

- Climate prediction;

- Exploration and exploitation ${ }^{4}$ of

- Natural resources; and

- Underwater cultural heritage (shipwrecks); and

- Monitoring and environmental assessment.

1 This article is based upon the revised Chapter (15) on marine data collection in J.A. ROACH And R.W. Smith, Excessive Maritime Claims (4th edition in preparation). An earlier version of this article appears in NoRdQuist, MOORE, BECKMAN AND LONG (EDs.), Freedom of Navigation ANd Globalization 285-302 (2015).

2 United Nations Convention on the Law of the Sea, opened for signature 10 December 1982 (entered into force 10 November 1994), 1833 UNTS 397 (hereinafter Los Convention or Convention).

3 The term is also used by the US Navy: "Marine data collection is a general term used when referring to all types of survey or marine scientific activity (e.g., military surveys, hydrographic surveys, and marine scientific research)." US Chief of Naval Operations, OPNAV Instruction 3128.9F, Diplomatic Clearance for US Navy Marine Data Collection Activities in Foreign Jurisdictions, 1 July 2014, para. 4.a, available at https://cyrptome.org/dodi/2014/opnav-3128-9f.pdf.

4 The term "exploitation" is used in the sense of resource development and management.

(C) J. ASHLEY ROACH, 2019 | DOI:10.1163/9789004379633_010

This is an open access article distributed under the terms of the prevailing CC-BY-NC License at the time of publication. 
The Los Convention uses, but does not define, the terms "marine scientific research," "hydrographic survey," "survey activities," "exploitation" or "exploration" and does not mention "military surveys," "operational oceanography" or their subcategories. Nevertheless, the concepts are distinct, and this article seeks to clarify those differences.

The relevant maritime zones where these activities take place are the territorial sea, the contiguous zone, the exclusive economic zone (EEz), the continental shelf, the deep seabed beyond the limits of national jurisdiction (the Area), straits used for international navigation, and archipelagic sea lanes.

This article examines what is involved in each of these activities, reviews the applicable legal regimes, and demonstrates that surveys, operational oceanography, exploration and exploitation, and monitoring and environmental assessment are not marine scientific research regulated by Part XIII of the LOS Convention; rather they are subject to separate legal regimes.

Even though none of these five categories and seven subcategories is defined in the law of the sea, including the Los Convention, it is necessary to understand what each entails to appreciate the legal regime applicable to each.

\section{US Views: What is MSR?}

The most heavily regulated is the first category, marine scientific research (MSR). The Los Convention devotes a whole part, Part XIII, containing 28 articles in six sections, to the subject of MSR. Although not defined in the Convention, "marine scientific research" is the general term most often used to describe those activities undertaken in the ocean and coastal waters to expand scientific knowledge of the marine environment and its processes. ${ }^{5}$

5 Office of Ocean and Polar Affairs, U.S. State Department, Marine Scientific Research Authorizations, available at https://www.state.gov/e/oes/ocns/opa/rvc/index.htm. Harriet Davies, The Regulation of Marine Scientific Research: Addressing Challenges, Advancing Knowledge, in Warner and Kaye (eds.), Routledge Handbook of Maritime Regulation ANd Enforcement 212 (2016); Stephens and Rothwell, Marine Scientific Research, in The OXford Handbook of the LaW of the Sea 561-562 (2015); G.K. Walker, General Editor, Definitions for the LaW of the Sea: Terms Not Defined by the 1982 CONVENTION 241 (2012), (recounting the unsuccessful attempts to define MSR during the Third UN Conference on the Law of the Sea (UNCLOS III)). Compare Los Convention, Articles 243 ("scientists ... studying the essence of phenomena and processes occurring in the marine environment and the interrelations between them" and 246(3) "to increase scientific knowledge of the marine environment for the benefit of all mankind"); A.H.A. Soons, MArine Scientific Research and the LaW of the SEA 124 (1982), [hereinafter, Soons]. See generally M. Gorina-Ysern, An International Regime for Marine Scientific ReSEARCh (2003). Japanese law does not define MSr. See Takada, Marine Scientific Research 
The United States accepts this definition. ${ }^{6}$ MSR includes physical oceanography, marine chemistry, marine biology, scientific ocean drilling and coring, geological/geophysical research, as well as other activities with a scientific purpose. It is distinguished from hydrographic surveys, from military activities (including military surveys), from operational oceanography, from exploration and exploitation of natural resources and underwater cultural heritage, ${ }^{7}$ and

in the Exclusive Economic Zone and Japan-China Agreement for Prior Notification (1995-2001), Japanese Digest of International Law JD(III) 3, 44 JAPANESE ANNUAL OF INTERNATIONAL LAW 2001134 (2002).

6 Marine Scientific Research Authorizations, supra note 5; OPNAV Instruction 3128.9F, supra note 3 , at para. 4.d.

7 Ibid. The State Department webpage reads:

While the Law of the Sea Convention does not define marine scientific research, the term generally refers to those activities undertaken in the ocean to expand knowledge of the marine environment and its processes. The United States has identified some marine data collection activities that are not marine scientific research. These include prospecting for and exploration of natural resources; hydrographic surveys (for enhancing the safety of navigation); military activities including military surveys; activities related to Part XII of the Convention; the collection of marine meteorological data and other routine ocean observations - such as those monitoring and forecasting of ocean state, natural hazard warnings and weather forecasting, and climate prediction - including through the voluntary ocean observation programs of the Joint Intergovernmental Oceanographic Commission-World Meteorological Technical Commission on Oceanography and Marine Meteorology (Јсомм) and the Argo program; and activities directed at objects of an archeological and historical nature found at sea.

The OPNAVINST reads as follows:

activities undertaken per Part XIII of [the Los Convention] in territorial seas, archipelagic waters, straits for navigation, the EEZ, high seas, on the continental shelf, or in the Area... The purpose of MSR is to expand general scientific knowledge of the marine environment. MSR activities undertaken include physical and chemical oceanography, marine biology, fisheries research, scientific ocean drilling and coring, geological/geophysical studies, and other activities with a scientific purpose. Data collected as a result of MSR is made publicly available. MSR does not include prospecting and exploration of natural resources, hydrographic surveys, or military activities. This includes military surveys and environmental monitoring and assessment pursuant to Section 4 of Part XII of [the LOS Convention], to include operational oceanography.

See US State Department, Commentary - The 1982 United Nations Convention on the Law of the Sea and the Agreement on Implementation of Part XI, US Senate Treaty Doc. 103-39, at 80, available at https://www.foreign.senate.gov/publications/download/treaty-doc-103-39-unitednations-convention-on-the-law-of-the-sea. (hereinafter US Commentary) (MSR differs from hydrographic surveys and resource exploration). In discussing MSR for military purposes, Professor Soons does not mention military surveys or other military activities. Soons, supra note 5 , at 135 .

More recently, Professors Stephens and Rothwell and Harriett Davies have addressed new technologies that were not addressed in Part XIII. Stephens and Rothwell, supra note 5 , at 562, 574-578; Davies, supra note 5 , at 223-224. 
from environmental monitoring and assessment pursuant to Section 4 of Part XII of the LOs Convention. Each of these is discussed in the following sections.

III

Surveys

For the purposes of this analysis, there are two forms of surveys, hydrographic surveys and military surveys.

\section{$1 \quad$ Hydrographic Surveys}

"Hydrographic surveys" are activities undertaken to obtain information for the making of navigational charts and for the safety of navigation. Hydrographic surveys include the determination of the depth of water, the configuration and nature of the sea floor, the direction and force of currents, heights and times of tides and water stages, and hazards to navigation. This information is used for the production of nautical charts and similar products to support safety of navigation, such as Sailing Directions, Light Lists and Tide Manuals for both civil and military use. ${ }^{8}$ Coastal, harbor and harbor approach charts of nonUS waters and other products are published by the US National GeospatialIntelligence Agency and made available to mariners of all countries. ${ }^{9}$

In many areas of the world, the production of up-to-date charts has had a positive impact on economic development in coastal areas, stimulating trade and commerce and the construction or modernization of harbor and port

8 Cf. Definition 46, in International Hydrographic Bureau, a Manual on Technical Aspects of the United Nations Convention on the LaW of the Sea-1982, 1-16 (2006), Appendix 1, available at http://www.iho.shom.fr/publicat/free/files/S-51_Ed4EN.pdf, and in OPNAVINST 3128.9F, supra note 3, at para. 4.c. ("Hydrographic survey refers to marine data collection activities undertaken in the territorial seas, archipelagic waters, straits for navigation, the EEZ, high seas, and on the continental shelf for the production of nautical charts and similar products to support safety of navigation. Hydrographic surveys can include one or more of several classes of data, such as depth of water, configuration and nature of the natural bottom, direction and force of currents, heights and times of tides and water stages, and hazards to navigation."). The definition of "hydrographic survey" in Walker, supra note 5 , is different:

"the science of measuring and depicting those parameters necessary to describe the precise nature and configuration of the seabed and coastal strip, its geographical relationship to the land mass, and the characteristics and dynamics of the sea.... Hydrographic surveys may be necessary to determine the features that constitute baselines or basepoints and their geographical position." Ibid., at 227.

9 10 U.S.C. $§ 451$ et seq. Nautical charts of US waters are produced by the Office of Coast Survey, National Oceanic and Atmospheric Administration (NOAA), available at https://www.nauti calcharts.noaa.gov/. 
facilities. By helping safety of navigation for ships in transit, up-to-date charts also play a role in protecting coastal areas from the environmental pollution which results from wrecks of ships carrying hazardous cargoes and freighters. Data collected during hydrographic surveys may also be of value in coastal zone management and coastal science engineering.

The UN General Assembly in its annual resolution on oceans and the law of the sea has recognized the importance of hydrographic surveys and nautical charting:

Recognizing further that hydrographic surveys and nautical charting are critical to the safety of navigation and life at sea, environmental protection, including the protection of vulnerable marine ecosystems, and the economics of the global shipping industry, and encouraging further efforts towards electronic charting, which not only provides significantly increased benefits for safe navigation and management of ship movement, but also provides data and information that can be used for sustainable fisheries activities and other sectoral uses of the marine environment, the delimitation of maritime boundaries and environmental protection ...

14. Encourages intensified efforts to build capacity for developing countries, in particular for the least developed countries and small island developing States, as well as coastal African States, to improve hydrographic services and the production of nautical charts, including electronic charts ...10

The 2016 resolution, after repeating the preambular paragraph quoted above, strengthened its operative paragraph on hydrographic surveys:

155. ... urges all States to work with [the International Hydrographic] Organization to increase the coverage of hydrographic information on a global basis to enhance capacity-building and technical assistance and to promote safe navigation, in particular through the production and use of accurate electronic navigational charts, especially in areas used for international navigation, in ports and where there are vulnerable or protected marine areas. ${ }^{11}$

\footnotetext{
10 UNGA Resolution A/RES $/ 67 / 78,11$ December 2012. Similar paragraphs appear in earlier resolutions A/Res/66/231, A/REs/65/37A, A/REs/64/71, A/REs/63/111, A/REs/62/215, $\mathrm{A} / \mathrm{RES} / 61 / 222, \mathrm{~A} / \mathrm{RES} / 60 / 30, \mathrm{~A} / \mathrm{RES} / 59 / 24$ and $\mathrm{A} / \mathrm{RES} / 58 / 240$, available at http://www .un.org/Depts/los/general_assembly/general_assembly_resolutions.htm.

11 UNGA Resolution A/RES/71/271, 23 December 2016, para. 155. Both paragraphs were repeated in resolution A/RES/72/73, 5 December 2017, at 4-5 and para. 158.
} 
Survey activities are not MSR. The LOS Convention distinguishes clearly between the concepts of "research" and "MSR" on the one hand, and "hydrographic surveys" and "survey activities" on the other hand. Article 19(2)(j) of the Los Convention includes "research or survey activities" as being inconsistent with innocent passage in the territorial sea. Article 21(1)(g) authorizes the coastal State to adopt laws and regulations, in conformity with the provisions of the Convention and other rules of international law, relating to innocent passage through the territorial sea in respect of "marine scientific research and hydrographic surveys." Article 40, entitled "research and survey activities," provides that in transit passage through straits used for international navigation, foreign ships, including "marine scientific research and hydrographic survey ships", may not carry out "any research or survey activities" without the prior authorization of the States bordering the straits. The same rule applies to ships engaged in archipelagic sea lanes passage (Article 54). While Part XIII of the LOS Convention fully regulates MSR, it does not refer to survey activities at all.

This conclusion, that MSR is distinct from survey activities, is supported by other respected publications on this subject. ${ }^{12}$

12 For example, the UN MSR Guide notes that "survey activities' ... are primarily dealt with in other parts ... of the Convention" rather than in Part XiII. UN, MARINE SCIENTIFIC Research: A Guide to the Implementation of the Relevant Provisions of the United Nations Convention on the LaW of the Sea 1 (1991), (hereinafter MSR Guide). This could indicate that these activities do not fall under the regime of Part XIII. The MSR Revised Guide states that "[ $\mathrm{t}$ ] he freedom [of scientific research] envisioned in Art. 87 is not limited to marine scientific research but also extends to such activities as hydrographic surveys." UN, Marine SCientific Research: A revised guide to THE IMPLEMENTATION OF THE RELEVANT PROVISIONS OF THE UNITED Nations Convention on the LAW of the Sea (2010), at 16 para. 56 (hereinafter MSR Revised Guide), available at http://www.un.org/Depts/los/doalos_publications/publicationstexts/ msr_guide\%202010_final.pdf. Professor Soons has written: "From articles 19, 21 and 40, which use the term "hydrographic surveying" separately from "research," it follows that the term "marine scientific research," for the purposes of the Draft Convention, does not cover hydrographic surveying activities." (Soons, supra note 5, at 125.) Later in the same book, Professor Soons wrote: "With respect to hydrographic surveying (an activity which is not to be considered marine scientific research, although it is somewhat similar to it ...), it is submitted that this activity, when it is conducted for the purpose of enhancing the safety of navigation ..., must be regarded as an internationally lawful use of the sea associated with the operations of ships ... in accordance with article 58 , and can therefore be conducted freely in the exclusive economic zone ...." (Soons, supra note 5 , at 157). The United Kingdom agrees. 68 British Yearbook of International LaW 609 (1997). See also Davies, supra note 5, at 220 et seq. and Stephens and Rothwell, supra note 5, at 570-572. A contrary position is taken by an Adjunct Senior Scholar at the National Institute for South China Seas Studies, Haikou, China, who argues, without supporting documentation, that the MSR consent regime was established in part because the information collected "may be used to undermine the security of the state." Valencia, Some "Scientific" 
The Convention therefore limits survey activities during passage in the territorial sea, in straits used for international navigation and in archipelagic sea lanes, but does not limit the activities of survey ships in the EEz.

Like MSR, survey activities in the territorial sea are expressly subject to coastal State consent. ${ }^{13}$

Again, like MSR, survey activities while in transit passage or archipelagic sea lanes passage with its concomitant rights are expressly subject to prior authorization of the States bordering straits or the archipelagic State. ${ }^{14}$

Seaward of the territorial sea, all States remain free to conduct surveys free of coastal State regulation or control. ${ }^{15}$

International law, as reflected in the Los Convention, authorizes coastal States to claim limited rights and jurisdiction in an EEz. The jurisdictional rights relate primarily to the exploration, exploitation, and conservation of natural resources, MSR, and the marine environment. Beyond the territorial sea, all States enjoy the freedoms of navigation and overflight and other related uses of the sea within the EEZ, provided that they do so with due regard to the rights of the coastal State and other States. ${ }^{16}$ The conduct of surveys in the EEZ is thus an exercise of the freedoms of navigation and other internationally lawful uses of the sea related to those freedoms, such as those associated with the operations of ships, which Article 58 of the Los Convention guarantees to all States. However, a hydrographic survey on a foreign continental shelf that involves exploration or exploitation of living or non-living resources of the continental shelf requires coastal State consent.

\section{$2 \quad$ Military Activities, including Military Surveys}

The Los Convention recognizes that all States have, within the EEZ, in contrast to the territorial sea, the right to conduct military activities, provided that they do so with due regard to the rights of the coastal State and other States (Article 58(3)). Appropriate activities include normal ship operations, task force maneuvering, launching and landing of aircraft, operating military devices, military exercises, intelligence collection, weapons exercises, ordnance testing, and military surveys. There is no general competence of the coastal State over military activities in the EEz. Therefore, military activities, including military

Surveys a Security Threat in the South China Sea, IPP Review, 9 November 2017, available at http://www.ippreview.com/index.php/Blog/single/id/584.html.

13 Arts. 19(2)(j) and 21(1)(g), Los Convention.

14 Arts. 40 and 54, Los Convention,

15 Arts. 56(1)(b)(ii), 78 and 87(1)(f), Los Convention.

16 Art. 58, Los Convention. 
surveys, conducted outside foreign territorial seas are not subject to coastal State regulation. ${ }^{17}$

"Military survey" refers to activities undertaken in territorial seas, archipelagic waters, straits used for international navigation, the EEZ, high seas, and on the continental shelf involving marine data collection (whether or not classified) for military purposes (e.g., not shared with the general public). Military surveys can include oceanographic, hydrographic, marine geological, geophysical, chemical, biological, acoustic, and related data. ${ }^{18}$

Military surveys are not specifically addressed in the Los Convention and there is no language stating or implying that military surveys may be regulated in any manner by coastal States outside their territorial sea or archipelagic waters. The United States therefore considers it to be fully consistent with the LOS Convention that the conduct of such surveys is a high seas freedom and the United States reserves the right to engage in military surveys anywhere outside foreign territorial seas and archipelagic waters. To provide prior notice or request permission would create an adverse precedent for restrictions on mobility and flexibility of military survey operations. However, a military survey on a foreign continental shelf that involves exploration or exploitation of living or non-living resources of the continental shelf requires coastal State consent. The US Navy requires that coastal State permission be sought if a military survey or hydrographic survey is planned to be conducted in foreign territorial seas, archipelagic waters or straits used for international navigation. ${ }^{19}$

These definitions thus clearly distinguish between MSR, which the coastal State can regulate, and hydrographic survey and military survey activities, which are freedoms the coastal State cannot regulate outside its territorial sea.

A few States have questioned the activities of military survey and hydrographic vessels in their EEzs. ${ }^{20}$ The United States has explained along the

17 See Art. 56, Los Convention, and Oxman, The Regime of Warships Under the United Nations Convention on the Law of the Sea, 24 Virginia Journal of InTERnational LaW 847 (1984).

18 OPNAV Instruction 3128.9F, supra note 3, at para. 4.b. ("Military survey refers to activities undertaken in territorial seas, archipelagic waters, straits for navigation, the EEZ, high seas, and on the continental shelf involving marine data collection (whether or not classified) for military purposes (e.g., not shared with the general public). Military surveys can include oceanographic, hydrographic, marine geological, geophysical, chemical, biological, acoustic, and related data.").

19 OPNAVINST $3128.9 \mathrm{~F}$, supra note 3 , at para. $6 . \mathrm{b}(2)$.

20 For example, China claims the right to approve all mapping and surveying activities in "sea areas under the jurisdiction of the People's Republic of China." Surveying and Mapping Law of the People's Republic of China, Presidential Order No. 75, 29 August 2002, effective 1 December 2002, Art. 2, available at http://www.asianlii.org/cn/legis/cen/laws/ samlotproc506/. 
foregoing lines why such survey activities are not subject to coastal State regulation..$^{21}$

\section{$3 \quad$ Operational Oceanography}

Operational oceanography is the routine collection of ocean observations, such as temperature, pressure, current, salinity and wind, in all maritime zones. It may be conducted in the oceans, at the air-sea interface, and in the atmosphere. This data is used for the monitoring and forecasting of weather (meteorology), climate and ocean state (e.g., surface currents and waves). The data is transmitted from sensor to shore in near real time and is made available to the public in near real time. ${ }^{22}$

The various operational oceanography programs and data collection instruments are described in Section 15.11 of the third edition of Excessive Maritime Claims and need not be repeated here. They are described there to facilitate a better understanding why they are, for the most part, conducted in the exercise of the high sea freedoms of navigation and overflight, and are not MSR governed by Part XIII of the LOS Convention. Nevertheless, some coastal States remain concerned that some or all of this data collected within their E Ezs may be of direct significance for the exploration and exploitation of natural resources, whether living or non-living, within their $\mathrm{EEzs}^{23}$ and thus wish to have some say as to the collection and use of that data. In that regard, the 2016 UNGA resolution on oceans and law of the sea stated in one of its preambular paragraphs:

Recognizing that ocean data buoys deployed and operated in accordance with international law are critical for improving understanding of weather, climate and ecosystems, and that certain types of ocean data buoys contribute to saving lives by detecting tsunamis, and reiterating its serious concern at intentional and unintentional damage to such buoys[.] $]^{24}$

21 State Department telegram 092114, 8 April 1994, para. 6; 2001 Digest of United States Practice in International Law 698-699 (hereinafter Digest); 2003 Digest, at 728, 738; 2007 Digest, at 647-650; 2009 Digest, at 468-469; 2012 Digest, at 420-421; 2015 Digest, at 524-525, all available at https://www.state.gov/s/l/c8183.htm.

22 Operational oceanography has also been defined "as the activity of systematic and long-term routine measurements of the seas and oceans and atmosphere, and their rapid interpretation and dissemination," available at http://eurogoos.eu/about-eurogoos/whatis-operational-oceanography/. See further, Davies, supra note 5, at 222-223.

23 Cf. Arts. 56(1)(a) and 246(5)(a), Los Convention.

24 UNGA Resolution A/RES/71/257, 23 December 2016, at 5; repeated in resolution $\mathrm{A} / \mathrm{RES} / 72 / 73,5$ Dec. 2017 , at 5 . 
The world's oceans exhibit wide variability on both spatial and temporal scales. While designated by basins (e.g., Atlantic, Pacific, Indian, Southern), boundaries used to delineate them are geographical and somewhat artificial as the oceans interact on global as well as regional scales. For example, changes in overturning circulations (North Atlantic, Southern Ocean) eventually will impact all of the ocean basins thereby manifesting changes regionally. Like the atmosphere, the oceans do not recognize geopolitical boundaries. Similarly, the oceans' interactions with the atmosphere often manifested through changes in weather and storm patterns are global processes, reflected regionally.

Understanding of the global ocean provides the context for understanding and predicting regional and coastal variability. The key to understanding is observations, observations of the oceans globally, regionally and locally. The operational ocean observing system allows nations to:

- monitor, understand and predict weather and climate;

- describe and forecast the state of the ocean, including living resources;

- improve management of marine and coastal ecosystems and resources;

- mitigate damage from natural hazards and pollution;

- protect life and property on coasts and at sea; and

- enable scientific research. ${ }^{25}$

In view of the United States, operational oceanography is not MSR. ${ }^{26}$ The large-scale programs of oceanographic data collection, described elsewhere, ${ }^{27}$ that operate independently from the users of the data distinguish operational oceanography from MSR.

\section{$4 \quad$ Marine Meteorological Data}

It should be recalled that the Third UN Conference on the Law of the Sea decided that the collection of marine meteorological data is not marine scientific research regulated by Part XIII of the Law of the Sea Convention.

25 These six bullets are what Goos is designed to do. See available at $\mathrm{http} / /$ www.ioc-goos.org/ index.php?option=com_content\&view=article\&id=12\&Itemid=26\&lang=en. "Enable" means observe from which hypotheses are developed and tested, not conduct scientific research. See Subramanian et al. (eds.), Impacts of Data Collected and Lessons Learned from OceanObserving Systems Worldwide, 5o Marine Te ChNology Society Journal (2016).

26 Senate Ex. Rep. 110-9, 19 December 2007, at 13, available at https://www.congress.gov/110/ crpt/erpt9/CRPT-11oerpt9.pdf ("there are other activities, such as operational oceanography, that are also not considered marine scientific research"). F.H.TH. WEgELEIN, MArine Scientific Research: The Operation and Status of Research Vessels ANd other Platforms in International LaW 116 (2005) notes that the procedures for advance access request to a coastal State is "impracticable" and the "scientific value of their measurements would be significantly impaired if drifters had to be retrieved before they enter foreign waters and not be re-released before permission is obtained; conversely, the exact date of entry can usually not be predicted ..., neither which foreign waters it may stray into." 
In 1979 the Eighth wMo Congress noted that the Members of the WMO engaged in operational activities, such as the collection of meteorological information from voluntary observing ships, buoys, other ocean platforms, aircraft and meteorological satellites, as well as meteorological and oceanographic research activities, considered that "adequate marine meteorological data coverage from ocean areas, in particular from those areas in the so-called "exclusive economic zone," is indispensable for the issue of timely and accurate storm warnings for the safety of life at sea and for the protection of life and property in coastal and off-shore areas," and that solas required States to issue warnings of gales, storms and tropical storms and to arrange for selected ships to take meteorological observations, ${ }^{28}$ expressed the hope that the provisions on marine scientific research then being negotiated by the Third UN Conference on the Law of the Sea "would not result in restrictions on operational meteorological and related oceanographic observational activities carried out in accordance with international programmes such as www and IGOss" and appealed to its Members to ensure that the Conference was "made aware of the vital need for observational data from sea areas for the timely issue of weather forecasts and storm warnings." 29

On 20 August 1980, after the completion of the negotiations on the MSR articles at the Resumed Ninth Session of the Conference, the Chairman of the Third Committee announced that he was now in a position to reply to the letter from the wмо forwarding this Resolution. The Chairman stated he agreed with the content of the Resolution and that

in his opinion, the provisions on marine scientific research would not create any difficulties and obstacles hindering adequate meteorological coverage from ocean areas, including areas within the exclusive economic zone, carried out both within the framework of existing international programs and by all vessels, since such activities had already been recognized as routine observations and data collecting which were not covered by Part XIII of the negotiating text. Furthermore, they were in the common interest of all countries and had undoubted universal significance. ${ }^{30}$

28 SOLAS 1960 , regulation V/4, 536 UNTS $325-328$. The current version is SOLAS 1974, regulation V/5 (rev. 2002), quoted in attachment 3 to Roach, Marine Data Collection: Methods and Law, in M. Nordquist, T. Koh and J.N. Moore (eds.), Freedom of the Seas, Passage Rights and the 1982 LaW of the Sea Convention 205-208 (2009).

29 wмо Res. 16 (Cg-VIII), United Nations Conference on the Law of the Sea, March 1979, Doc. A/CONF.62/80, 9 Aug. 1979, XII Official Records of the Third UN Conference on the Law of the Sea, at 56 (hereinafter, Official Records), available at http://legal.un.org/diplomaticconferences/1973_los/voli2.shtml. 
Chairman Yankov repeated these comments in his Report of the Third Committee to the Plenary, without objection, ${ }^{31}$ and so wrote to the wMO on 25 August 1980.

The wMo continues to be committed to the free and unrestricted international exchange of basic meteorological data and products which are necessary for the provision of services in support of the protection of life and property and the well-being of all nations, particularly those basic data and products required to describe and forecast accurately weather and climate. Members of the wмо are obligated under Article 2 of the wмо Convention, inter alia, to facilitate worldwide cooperation in the establishment of observing networks. ${ }^{32}$

The importance of marine meteorological data was recognized in the 2016 UNGA resolution on oceans and the law of the sea, as follows:

Also recognizes the importance of navigational warning series based on marine meteorological data for the safety of ships and lives at sea and the optimization of navigation routes, and notes the collaboration between the World Meteorological Organization and the International Maritime Organization for the enhancement of these services and their extension to the Arctic region. ${ }^{33}$

\section{Exploration and Exploitation}

The Los Convention contains separate regimes for exploration and exploitation of natural resources and for underwater cultural heritage.

\section{$1 \quad$ Natural Resources}

Exploration and exploitation of natural resources involves the searching for and removal of living or non-living natural resources found in the oceans or beneath the seabed. The term "natural resources" has four separate meanings in the law of the sea, depending on the maritime zone where they are located. First, the natural resources governed by the EEZ regime are the living and nonliving natural resources (not further expressly defined) located within the E Ez. ${ }^{34}$

31 Report of the Chairman of the Third Committee, Doc. A/conf.62/L.61, 25 August 1980, para. 8, XIV OfFicial Records, 133-134; XIV OfFicial Records, at 15, para. 43.

32 WMO 12th Congress resolution 40 (Cg-XII) (1995), available at www.wmo.int/pages/ about/resolution4o_en.html.

33 UNGA Resolution A/RES/71/257, 23 December 2016, para. 156; repeated in resolution A/RES/72/73, 5 Dec. 2017, para. 159 . 
Second, the natural resources governed by the continental shelf regime are the mineral and other non-living resources of the seabed and subsoil, together with the living organisms belonging to sedentary species..$^{35}$ Third, the natural resources of the deep seabed beyond the limits of national jurisdiction (the Area) are all solid, liquid or gaseous mineral resources in situ in the Area at or beneath the seabed, including polymetallic nodules; ${ }^{36}$ this definition does not include living marine resources. Fourth, the natural resources of the high seas regime are referred to as "the living resources of the high seas" and include fish and marine mammals. ${ }^{37}$

Part v of the Los Convention regulates exploration for and exploitation of the living and non-living natural resources located within the EEZ separately from the conduct of MSR within the EEZ. ${ }^{38}$ Part VI of the Convention governs exploration for and exploitation of the mineral and other non-living resources of the seabed and subsoil, i.e., the continental shelf, together with living organisms belonging to sedentary species. ${ }^{39}$ Part VI does not address MSR at all. ${ }^{40}$ Thus it follows that, even though exploration and exploitation in both maritime zones are subject to exclusive coastal State control, those activities are not MSR. ${ }^{41}$

Part XI of the Convention and its Implementing Agreement regulate exploration for and exploitation of all solid, liquid or gaseous mineral resources in situ in the deep seabed beyond the limits of national jurisdiction at or beneath the seabed, including polymetallic nodules. Exploration and exploitation in the Area are subject to regulation by the International Seabed Authority. Article $25^{6}$ provides that MSR in the Area is to be conducted in conformity with Part XI, particularly Article 143. Hence, exploration and exploitation of mineral resources in the Area is not MSR regulated by Part XIII.

35 Art. 77(4), Los Convention. Sedentary species are those organisms which, at the harvestable stage, either are immobile on or under the seabed or are unable to move except in constant contact with the seabed or subsoil. Ibid.

36 Art. 133, Los Convention. When recovered from the Area, these resources are referred to in the Convention as "minerals."

37 Part VII, Section 2, Arts. 116-120, Los Convention.

38 Compare Arts. 56(1)(a) and 56(1)(b)(ii), Los Convention.

39 Art. 77, Los Convention.

40 MSR in the EEZ and on the continental shelf is regulated by Part XIII, Article 246 of the Convention.

41 Because they directly implicate exploration or exploitation of the natural resources of the continental shelf, Article 246(5) permits a coastal State to withhold its consent to the conduct of a MSR project on its continental shelf, inter alia, if (a) it is of direct significance for the exploration and exploitation of natural resources, whether living or non-living, (b) involves drilling into the continental shelf, or (c) involves the construction, operation or use of artificial islands, installations and structures. 


\section{Underwater Cultural Heritage $(\mathrm{UCH})$}

Exploration and exploitation of underwater cultural heritage involves the search for, recording of, and removal of items of cultural heritage, such as artifacts from shipwrecks. These items are, of course, not natural but are manmade resources.

UCH is addressed in only two articles of the Los Convention, Article 303 with regard to the contiguous zone, and Article 149 with regard to archaeological and historical objects found in the Area. UNEsco has developed a regulatory scheme for $\mathrm{UCH}$ found at sea that seeks to provide coastal States authority to regulate the search for and recovery of $\mathrm{UCH}$ located landward of the outer limit of a declared contiguous zone, and seaward of such a zone contrary to the allocation of rights and duties in the Los Convention. ${ }^{42}$

Exploration for and exploitation of $\mathrm{UCH}$ is also not MSR. ${ }^{43}$

Section 4 of Part XII on the protection and preservation of the marine environment requires monitoring and environmental assessment of the risks or effect of pollution of the marine environment. In particular Article 204(1) requires States "to observe, measure, evaluate and analyze, by recognized scientific methods" these risks or effects. Article 204(2) requires States to keep under surveillance the effects of certain activities in order to determine whether these activities are likely to pollute the marine environment. Article 205 requires States to publish reports of the results obtained. Article 206 requires States to assess certain activities. All of these requirements are inconsistent with the MSR regime of Part XIII. Accordingly, monitoring and environmental assessment pursuant to Section 4 of Part XII is not MSR. ${ }^{44}$

VI

\section{Legal Regimes of MSR and Surveys under the 1958 Geneva Conventions}

Prior to UNCLOS III, each coastal State possessed sovereignty over a narrow territorial sea and sovereign rights over its continental shelf for the purpose of exploring and exploiting its natural resources. High seas freedoms, including

42 Convention on the Protection of Underwater Cultural Heritage, Paris, 2001, available at http://unesco.org/new/en/culture/themes/underwater-cultural-heritage/2001-conven tion/officialtext. For details, see Roach and Smith, supra note 1, at 549-552.

43 Wegelein, supra note 26 , at 218-219.

44 OPNAV Instruction 3128.9F, supra note 3, para. 4.d. 
the freedom to conduct surveys and MSR, appertained in the water column seaward of the territorial sea, and on the seabed seaward of the outer limits of the continental shelf.

The United States is a party to the four 1958 Geneva Conventions on the Law of the Sea, which established a regime - of sorts—for surveys and MSR.

The Continental Shelf Convention recognizes coastal State jurisdiction over MSR involving the continental shelf and physically undertaken there, but is silent regarding surveys. The coastal State is normally expected to give its consent if the request is in connection with purely scientific research and is submitted by a qualified institution. The coastal State has the right to participate or be represented in the research. The results of the research must be published. ${ }^{45}$

The High Seas Convention, expressly codifying customary international law, recognizes the freedom of the seas, including the water column over the continental shelf, without specifically mentioning MSR or surveys among its illustrative list of freedoms. ${ }^{46}$ Nevertheless, the conduct of MSR was regarded as an exercise of the freedom of the high seas. ${ }^{47}$

The Territorial Sea Convention is silent on MSR and surveys, except to provide that the territorial sea and subjacent seabed and subsoil are under the sovereignty of the coastal State. ${ }^{48}$ It follows that the consent of the coastal State must be obtained for research work in and under its territorial sea. ${ }^{49}$

The 1958 Fishing Convention is silent on marine scientific research.

Thus, the four 1958 Geneva Conventions contain very little treaty law on MSR and marine surveys. Nevertheless, prior to the Los Convention, freedom to conduct MSR and marine surveys existed in most of the oceans seaward of the narrow territorial sea, and on the seabed seaward of 200 meters depth or where the continental shelf could not be exploited.

The 1958 regime is replaced by the detailed regime set out in the Los Convention, for States parties to these treaties. ${ }^{50}$

451958 Convention on the Continental Shelf, 499 UNTS 311, Arts. 5(1) \& (8). Soons, supra note 5 , at $5^{6-58}$ examines the meaning of these two paragraphs, concluding that the customary international law rules are essentially the same as those set out in paragraphs 1 and 8 of article 5 .

$46 \quad 1958$ Convention on the High Seas, 450 UNTS 82, Art. 2.

47 The United Kingdom agreement with the position may be found in 56 BRITISH YEARвоOK OF International LAW 1985501 (1986). The United States concurs in this position. Professor Soons came to the same conclusion after reviewing the travaux préparatoires, state practice and the views of publicists. Soons, supra note 5 , at $47-55$.

481958 Territorial Sea Convention, 516 UNTS 205, Arts. 1-2.

4956 British YeArbook of Inte Rnational LaW 1985501 (1986); Soons, supra note 5 , at 46.

$50 \quad$ Art. 311(1), Los Convention. On the MSR regimes in the $195^{8}$ Geneva Conventions and Los Convention see also Stephens and Rothwell, supra note 5 , at 563-576. 
During the decade-long negotiations that culminated in the opening for signature on 10 December 1982 of the Los Convention, the United States sought to maximize the areas in which MSR could continue to be conducted free of coastal State control, to create a regime that maximized timely and unencumbered access by foreign researchers to areas under coastal State jurisdiction, and to maintain the right to conduct marine surveys seaward of the territorial sea free of coastal State control. These negotiations were conducted in the context of increasing acceptance of a 12-mile territorial sea under coastal State sovereignty, of the 200-mile exclusive economic zone (EEZ) under coastal State jurisdiction for economic purposes, and of an expanded continental shelf that was at least 200 miles wide, and could be even wider for the broad-margin States such as the United States.

The results of those difficult negotiations resulted in a diminution of the oceanic areas in which there was freedom of MSR, coupled with a consent regime for MSR in the EEZ and on the subjacent continental shelf, ${ }^{51}$ as set out in Part XIII of the Convention, while the freedom to conduct surveys was largely unchanged. ${ }^{52}$ In 1983, the President decided that, Part XI aside, the rest of the Los Convention supported US interests, including that of encouraging freedom of MSR. ${ }^{53}$

During the decades following adoption of the Los Convention, questions arose as to the legal status of the non-seabed provisions of the Los Convention. Some of its provisions-mostly coastal State rights, including the right to control MSR have been widely accepted and thus came to be considered as part of international law. However, other provisions - mostly duties, including coastal State duties to foreign researchers regarding MSR - have not been adequately followed and thus are clearly binding only on States party to the Convention.

Within the territorial sea, the coastal State exercises complete sovereignty, and MSR is now clearly under its exclusive control. The LOS LOS Convention explicitly provides that the coastal State has "the exclusive right to regulate, authorize and conduct" MSR in its territorial sea, which may be "conducted only with the express consent of and under the conditions set forth by the

$5^{1} \quad$ Soons, supra note 5 , at 261.

52 Annick de Marffy, Marine Scientific Research, in 2 Dupuy \& Vignes (eds.), A HandBoOK ON THE NeW LAW OF THE SEA 1140 (1991), ("the balance is tipped much more in favor of coastal States than in favor of researching States, and this is perhaps harmful to scientific research in general").

53 President's Ocean Policy Statement of 10 March 1983, available at http://www.un.org/ Depts/los/LEGISLATIONANDTREATIES/PDFFILES/USA_1983_Statement.pdf. See further Section 10 infra. 
coastal State. ${ }^{54}$ Further, the Los Convention expressly states that the "carrying out of research or survey activities" makes passage through the territorial sea not innocent ${ }^{55}$ and expressly authorizes the coastal State to enact laws and regulations relating to innocent passage through the territorial sea in respect of "marine scientific research" as well as "hydrographic surveys."

Under the Los Convention, the regime of passage through straits used for international navigation does not in other respects affect the legal status of the waters forming such straits or the exercise by the States bordering the straits of their sovereignty or jurisdiction over such waters. ${ }^{57}$ Accordingly, Article 40 provides that during transit passage through such straits, foreign ships, "including marine scientific research and hydrographic survey ships," may not carry out any research or survey activities" without the prior authorization of the States bordering straits. The same rules apply to archipelagic sea lanes passage. ${ }^{58}$

International law now recognizes the right of all coastal States to claim E EZs that may extend seaward 200 miles from their territorial sea baselines. Indeed, some 126 coastal States have done so. ${ }^{59}$ International law further recognizes that within its EEZ a coastal State may exercise "jurisdiction as provided for in the relevant provision of [the LOS] Convention" over MSR. ${ }^{60}$ International law also now recognizes the sovereign right of the coastal State to explore and exploit the natural resources of its continental shelf, which may, as in the case of the United States, extend beyond 200 miles, but in most cases no more than 350 miles from the territorial sea baseline.$^{61}$ The Convention provides the legal framework for the exercise of MSR jurisdiction in the $\mathrm{EEZ}^{62}$ and on the continental shelf. ${ }^{63}$

54 Art. 245, Los Convention.

55 Art. 19(2)(j), Los Convention.

56 Art. 21(1)(g), Los Convention.

57 Art. 34(1), Los Convention.

$5^{8}$ Art. 54, Los Convention.

59 See Roach and Smith (3rd ed.), supra note 1, Chapter 7, Table 10.

6o Art. 56(1)(b)(ii), Los Convention.

61 Art. 76, Los Convention. See Roach ANd Smith (3rd ed.), supra note 1, Chapter 8 for details.

62 Arts. 246,248 and $25^{2-253}$, LOS Convention set the conditions for the conduct of MSR in the EEZ. In particular, six months advance request is required and the results of the research cannot be distributed publicly until the results of the research are compiled and shared with the coastal State. Further, the coastal State may, in its discretion, withhold consent to the conduct of a MSR project of another State in its EEZ or on its continental shelf if the project, inter alia, is of direct significance for the exploration or exploitation of its natural resources, whether living or non-living, within its EEz. Art. 246(5)(a), LOS Convention.

63 Art. 252, LOS Convention, sets similar conditions for the conduct of MSR on the continental shelf. 
Seaward of the EEZ are the high seas, and seaward of the continental shelf lies the seabed beyond the limits of national jurisdiction. Here the Los Convention clearly advances the rights of the scientific community by expressly recognizing, for the first time, that MSR is a freedom of the high seas that may be exercised by all States. ${ }^{64}$ Further, all States, as well as the International Seabed Authority, are permitted to carry out MSR on the seabed beyond national jurisdiction. ${ }^{65}$ On the other hand, the Los Convention is silent regarding survey activities seaward of the territorial sea.

\section{$1 \quad$ Conduct of MSR under the LOS Convention}

The conduct of MSR is fully regulated by Part XIII of the LOS Convention which does not address or apply to marine surveys of any sort. The Convention confirms the right of all States and competent international organizations to conduct $\mathrm{MSR}^{66}$ and the duty to facilitate the conduct of MSR in accordance with the terms of the Convention. ${ }^{67}$ The Convention sets forth the rights and obligations of States and competent international organizations with respect to the conduct of MSR in different maritime areas. ${ }^{68}$

1.1

Territorial Sea

Article 245 recognizes the unqualified right of coastal States to regulate, authorize and conduct MSR in the territorial sea. Therefore, access to the territorial sea, and the conditions under which a research project can be conducted there, are under the exclusive control of the coastal State. ${ }^{69}$

1.2 Archipelagic Waters

As archipelagic waters are under the sovereignty of the archipelagic State, MSR there is subject to the consent of that State. ${ }^{70}$

1.3 International Straits and Archipelagic Sea Lanes

Part XIII contains no provisions specifically targeted to straits used for international navigation or archipelagic sea lanes. However, under article 40, during transit passage, ships "may not carry out any research ... activities without the

\footnotetext{
64 Arts. 87(1)(f) and 257, LOs Convention.

65 Arts. 143 and 256, LOs Convention.

66 Art. 238, Los Convention.

67 Art. 239, LOs Convention.

68 See UN, MSR Revised Guide, supra note 12, at 3-25 for a detailed summary.

69 See also, Arts. 21(1)(g), 19(2)(j)), 40 and 54, LOS Convention. There is no appeal if consent is refused or unreasonable conditions are imposed. 56 BRITISH YEARBook OF INTERNATIONAL LAW 1985501 (1986).

70 Soons, supra note 5 , at 153 .
} 
prior authorization of the States bordering straits." The same rule applies to such ships exercising the right of archipelagic sea lanes passage. ${ }^{71}$

1.4

EEZ and Continental Shelf

Under Article 246, coastal States have the right to "regulate, authorize and conduct" MSR in the EEZ and on the continental shelf. Access by other States or competent international organizations to the EEZ or continental shelf for a MSR project is subject to the consent of the coastal State. The consent requirement, however, is to be exercised in accordance with certain standards and qualifications.

In normal circumstances, the coastal State is under the obligation to grant its consent to requests to conduct MSR in its EEZ or on its continental shelf. (It is explicitly provided that circumstances may be normal despite the absence of diplomatic relations. ${ }^{72}$ ) The coastal State, nevertheless, has the discretion to withhold its consent if the research project is of direct significance for the exploration and exploitation of living or non-living resources; involves drilling, the use of explosives or introduction of harmful substances into the marine environment; or involves the construction, operation and use of artificial islands, installations or structures. ${ }^{73}$ (The first of these grounds for withholding consent may be used on the continental shelf beyond 200 miles only in areas specially designated as under development. ${ }^{74}$ ) It may also withhold consent if the sponsor of the research has not provided accurate information about the project or has outstanding obligations in respect of past projects. ${ }^{75}$ If requested, the coastal State must state the reasons for denying consent. ${ }^{76}$ Otherwise, the researching State will not be in a position to determine what adjustments would be required to enable the project to proceed.

The consent of a coastal State for a research project may be granted either explicitly or implicitly. Article 248 requires States or organizations sponsoring projects to provide to the coastal State, at least six months in advance of the expected starting date of the research activities, a full description of the project. The research activities may be initiated six months after the request for consent, unless the coastal State, within four months, has informed the State or organization sponsoring the research that it is denying consent for one of the

$71 \quad$ Art. 54, LOs Convention.

72 Art. 246(3)-(4), Los Convention.

73 Art. 246(5)(a-c), Los Convention.

74 Art. 246(6), Los Convention.

75 Art. 246(5)(d), LOS Convention.

76 Center for Ocean law and Policy, University of Virginia School of LaW, United Nations Convention on the LaW of the Sea 1982: A Commentary, Volume 4, 519 (1991), at para. 246.17(d). 
reasons set forth in Article 246 or that it requires more information about the project. If the coastal State fails to respond to the request for consent within four months following notification, consent may be presumed to have been granted. ${ }^{77}$ This provision seeks to encourage timely responses from coastal States to requests for consent, which as noted below is not always the case.

Consent may also be presumed under Article 247 to have been granted by a coastal State for a research project in its EEZ or on its continental shelf undertaken by a competent international organization of which it is a member, if it approved the project at the time that the organization decided to undertake the project and it has not expressed any objection within four months of the notification of the project by the organization to the coastal State.

Article 249 sets forth specific conditions with which a State or competent international organization sponsoring research in the EEZ or on the continental shelf of a coastal State must comply. These include the right of the coastal State to participate in the project, in particular through inclusion of scientists on board research vessels; provision to the coastal State of reports and access to data and samples; assistance to the coastal State, if requested, in assessing and interpreting data and results; and ensuring that results are made internationally available as soon as practicable. Additional conditions may be established by the coastal State with respect to a project falling into a category of research activities over which the coastal State has discretion to withhold consent pursuant to Article 246.

If a State or competent international organization sponsoring research in the EEZ or on the continental shelf of a coastal State fails to comply with such conditions, or if the research is not being conducted in accordance with the information initially supplied to the coastal State, Article 253 authorizes the coastal State to require suspension of the research activities. If those carrying out the research do not comply within a reasonable period of time, or if the non-compliance constitutes a major change in the research, the coastal State may require its cessation.

1.5 The High Seas and the Area

Article 87 expressly recognizes conduct of MSR as a freedom of the high seas. Articles 256 and 257 further clarify that MSR may be conducted freely by any State or competent international organization in the water column beyond the limits of the EEZ, as well as in the Area, i.e., the seabed and ocean floor, and the subsoil thereof, beyond the limits of national jurisdiction. ${ }^{78}$ Under

77 LOs Convention, Art. 252, Los Convention.

78 If no EEZ is claimed, continental shelf restrictions apply only as stated in Article 246 . 
Article 143, research in the Area is to be carried out exclusively for peaceful purposes.

1.6 Research Installations and Equipment

The conditions applicable to MSR set forth in the Convention apply equally to the deployment and use of installations and equipment to support such research seaward of the territorial sea baseline. ${ }^{79}$ Such installations and equipment do not possess the status of islands, though safety zones of a reasonable breadth (not exceeding 500 meters) may be created around them, consistent with the Convention. They may not be deployed in such fashion as to constitute an obstacle to established international shipping routes. They must bear identification markings indicating the State of registry or the international organization to which they belong, and have adequate internationally agreed warning signals. ${ }^{80}$

\subsection{Responsibility and Liability}

Pursuant to Article 263(1), States and competent international organizations shall be responsible for ensuring that MSR, whether undertaken by them or on their behalf and wherever conducted seaward of the territorial sea baseline, is conducted in accordance with the Los Convention. Pursuant to Article 263(2), States and organizations shall be responsible and liable for any measures they take in contravention of the Convention in respect of research by other States, their natural or juridical persons or by competent international organizations and shall provide compensation for damage resulting from such measures. With respect to damage caused by pollution of the marine environment arising out of MSR undertaken by or on the behalf of States and competent international organizations, such States or organizations shall be liable pursuant to Article $235{ }^{81}$

\section{US Marine Scientific Research Policy}

The LOS Convention solidifies coastal State control over MSR in waters subject to their jurisdiction, waters which now encompass considerably more of the globe than in $1958 .^{82}$ Nevertheless, US policy is to encourage freedom of

\footnotetext{
79 Art. 258, Los Convention.

8o Arts. 259-262, Los Convention. See further Stephens and Rothwell, supra note 5, at 574-576.

81 Art. 263(3), LOS Convention.

82 Accompanying Germany's instrument of accession to the Los Convention was a declaration concerning MSR, which reads as follows:
} 
MSR. That policy was fostered by the US decision, first stated in the President's Oceans Policy Statement of 10 March $1983,{ }^{83}$ and reaffirmed in October 1994, in the documents transmitting the Los Convention to the US Senate for its advice and consent to accession, ${ }^{84}$ not to claim jurisdiction over MSR in its EEZ. The United States declined to assert jurisdiction in its EEZ over MSR because of its interest in encouraging MSR and promoting its maximum freedom while avoiding unnecessary burdens. The Department of State is charged with facilitating access by US scientists to foreign EEZs under reasonable conditions. Consequently, since 1983 the US requests permission through diplomatic channels for US research vessels to conduct MSR within 200 miles of a coastal State asserting such jurisdiction. ${ }^{85}$

Although the traditional freedom of research suffered a considerable erosion by the Convention, this freedom will remain in force for States, international organizations and private entities in some maritime areas, e.g., the sea-bed beyond the continental shelf and the high seas. However, the exclusive economic zone and the continental shelf, which are of particular interest to marine scientific research, will be subject to a consent regime, a basic element of which is the obligation of the coastal State under article 246, paragraph 3, to grant its consent in normal circumstances. In this regard, promotion and creation of favorable conditions for scientific research, as postulated in the Convention, are general principles governing the application and interpretation of all relevant provisions of the Convention.

The marine scientific research regime on the continental shelf beyond 200 nautical miles denies the coastal State the discretion to withhold consent under article 246, paragraph $5(a)$, outside areas it has publicly designated in accordance with the prerequisites stipulated in paragraph 6 . Relating to the obligation, to disclose information about exploitation or exploratory operations in the process of designation is taken into account in article 246 , paragraph 6 , which explicitly excluded details from the information to be provided.

UN, Multilateral Treaties Deposited with the Secretary-General: Status, available at http://treaties.un.org/pages/Participation/Status.aspx. (hereinafter UN, Multilateral Treaties Deposited).

83 When claiming its EEZ in 1983, the United States chose not to assert the right of jurisdiction over msr within the zone. President Reagan explained the rationale for not doing so, as follows:

While international law provides for a right of jurisdiction over marine scientific research within such a zone, the proclamation does not assert this right. I have elected not to do so because of the United States interest in encouraging marine scientific research and avoiding any unnecessary burdens. The United States will nevertheless recognize the right of other coastal states to exercise jurisdiction over marine scientific research within 200 nautical miles of their coasts, if that jurisdiction is exercised in a manner consistent with international law.

President's Ocean Policy Statement, supra note 53.

84 US Commentary, supra note 7 , at 80.

85 The United Kingdom similarly acts on behalf of British scientists seeking authorization to conduct MSR in foreign waters. See, 56 BRITISH YEARBOoK OF INTERNATIONAL LAW 
The United States does not require its permission to conduct MSR in US waters unless any portion of the MSR is conducted within the US territorial sea, any portion of the MSR within the US EEZ is conducted within a national marine sanctuary, a marine national monument, or other marine protected areas (16 US Code $\S 1436)$, any portion of the MSR within the US EEZ involves the study of marine mammals or endangered species (16 US Code $\S \S 1371(\mathrm{a})(1), 1374(\mathrm{c})$, 1538), any portion of the MSR within the US EEZ requires taking commercial quantities of living marine resources (16 US Code $\$ 1857(2)$ \& (4)), any portion of the MSR within the US EEZ involves contact with the US continental shelf (43 US Code $\S 1340$ ), or any portion of the MSR involves ocean dumping research (33 US Code $\S 1443$ ). The United States has identified some marine date collections activities that are not MSR, as discussed in Sections 3-6 above. ${ }^{86}$

Role of the US State Department in MSR

Within the Bureau of Oceans and International Environmental and Scientific Affairs (OES) is the Office of Ocean and Polar Affairs (OPA). OPA is responsible for assuring that US MSR policy is adhered to in acquiring permission from the coastal State, when required for such research, and for coordinating and processing of the requests, as well as in processing requests from foreign researchers to conduct MSR in the US territorial sea. All applications for consent must be submitted to OPA via the Research Application Tracking System (RATS), an online data management system designed to improve the transparency and efficiency of OPA's implementation of the marine scientific research consent regime. ${ }^{87}$

\section{Coastal State Practice Regarding MS R under the Los Convention}

Many coastal States are complying with the MSR regime of the LOS Convention, ${ }^{88}$ perhaps in no small part with the assistance of a practical guide to

1985500 (1986). The United States would similarly request permission to conduct MSR on a continental shelf seaward of the $200 \mathrm{~nm}$ limit.

86 Marine Science Research Authorizations, supra note 5. The requirements of other countries may be viewed at http://www.state.gov/www/global/oes/oceans/notices.html (notices to research vessel operators 1976-1999). See also http://www.unols.org/publications/index .html\#foreign.

87 Office of Oceans and Polar Affairs, Research Application Tracking System (RATs), available at https://www.state.gov/e/oes/ocns/opa/rvc/rats/index.htm.

88 Between 1983 and 1995, the US Department of State processed over 1600 requests for US research vessels to conduct MSR in territorial seas and EEzs of 140 States. Only 43 were 
the implementation of the MSR provisions first published in 1991 by the UN's Office for Ocean Affairs and the Law of the Sea ${ }^{89}$ and revised in $2010 .{ }^{90}$ The Revised Guide "strongly encourage[s]" States to "harmonize their national legislation with the provisions of the Convention, and, where applicable, relevant agreements and instruments, to ensure consistent application of those provisions." ${ }^{91}$

There are, however, a number of States that are not complying with the Convention's MSR provisions. Some of them are party to the Convention (e.g., Brazil, Chile, Mexico, Russia); others are not (e.g., Colombia). The problems the United States has encountered include the following:

- delays in responding to requests for ship clearances; ${ }^{92}$

- last minute denial of permission to conduct the research; ${ }^{93}$

- requiring all data, regardless of format, be provided immediately prior to departure from last port of call; 94

denied, and 148 were cancelled, principally because of the researchers non-compliance with the MSR regime. The various legislative enactments were briefly summarized in UN Division for Ocean Affairs and the Law of the Sea, Office of Legal Affairs, The Law of the Sea: Practice of States at the time of entry into force of the United Nations Convention on the LaW of the Sea 18, 37$38,75^{-76}, 83^{-84}, 97-98,134-135$ and 182 (1994). National legislation is collected in UN Office for Ocean Affairs and the law of the Sea, The law of the Sea: National Legislation, Regulations and Supplementary Documents on Marine Scientific Research in Areas under National Jurisdiction (1989).

$89 \mathrm{UN}$, MSR Guide, supra note 12. This pamphlet also suggests standardization of the forms for seeking consent and for granting permission to conduct MSR in areas of national jurisdiction.

$90 \quad \mathrm{UN}$, MSR Revised Guide, supra note 12.

91 Ibid., at 37, para. 129, citing the general call for harmonization of national legislation in the annual oceans and law of the sea resolution, A/REs/63/111, para. 5 (2008).

92 The last sentence of Article 246(3) requires coastal States to establish rules and procedures ensuring that consent will not be delayed or denied unreasonably. The UN MSR Guide states the coastal State "should therefore respond as quickly as can reasonably be expected to requests for consent." UN, MSR Guide, supra note 12, at 11, para. 52. The Revised Guide states "it would be helpful of the coastal State could respond as quickly as can reasonably be expected to requests for consent." UN, MSR Revised Guide, supra note 12, at 41, para. 150 .

93 Ibid.

94 Article 249(1)(b) sets no fixed time-limits for providing the preliminary reports, final results and conclusions of the research to the coastal State. Providing even a preliminary report prior to the ship"s departure is not practicable. Soons, supra note 5 , at 19o. Common practice is to provide the preliminary report 30 days after completion of the field portion of the research. 
- requiring the data to be provided within a fixed time after leaving the coastal State's waters, rather than after completion of the cruise; 95

- requiring copies of data collected in international waters, or in waters under another's country's jurisdiction; ${ }^{96}$

- requiring data to be held in confidence and not placed into the public domain; ${ }^{97}$

- requiring the cruise reports to be submitted in other than English;98

- requiring more than one observer to be on board; 99

- requiring the observer to be on board during non-research legs of a voyage;100

- requiring research and port call requests to be submitted other than through the Foreign Ministry; ${ }^{101}$

95 The UN MSR Guide states that "[a]ll efforts should be made to supply the final results and conclusions within a reasonable period of time" noting that the "time span between the end of the cruise and the availability of the final results can vary substantially depending upon the nature of the research." UN, MSR Guide, supra note 12, at 19 para. 92; UN, MSR Revised Guide, supra note 12, at 45, para. 170. Final reports usually take a year or longer to prepare.

96 The coastal State has no right under the Convention to receive such data until it is made public.

97 Article 249(1)(e) requires the data be made internationally available, unless it is of direct significance for the exploration and exploitation of natural resources. US law requires that US government-funded data must become part of the public domain unless classified or restricted for national security reasons. 44 US Code $\S \S 3501(2) \& 3506(d)(1)$, as amended by the Paperwork Reduction Act of 1995, Pub. L. 104-113.

98 The Convention is silent on this question. The UN MSR Guide recommends that consideration be given to providing the coastal State with reports "written in a language which can be read by scientists of the coastal State." UN, MSR Guide, supra note 12, at 19, para. 93; $\mathrm{UN}$, MSR Revised Guide, supra note 12, at 45 para. 171.

99 The right to participate under article $249(1)(a)$ is qualified to the extent that it must be "practicable." The UN MSR Guide notes that, if the right to participate is to be meaningful at all, the researching State "must always reserve space for at least one coastal State scientist on board," while recognizing only in extreme situations would that be impracticable, such as on a two- or three-man submersible. The Guide also cautions that "excessive demands should not be made." UN, MSR Guide, supra note 12, at 16, para. 78. Consistent with the UN MSR Guide's conclusion that "[ $\mathrm{t}]$ he coastal State may be able to claim more than one participant only if, and to the extent that, there is space available," two scientific participants are generally permitted on board US research vessels when space allows. However, there may be occasions when participation is not practical, or, conversely, when more than two may participate. Soons, supra note 5 , at 189 . Similar advice is not contained in the MSR Revised Guide.

100 This is not authorized by Article 249.

101 Under Article 250, all communications concerning MSR projects "shall be made through appropriate official channels, unless otherwise agreed." Soons states that it is always most 
- Foreign Ministry's failing to forward cruise reports to cognizant organization; ${ }^{102}$ and finally

- Slow or incomplete staffing and coordination among interested coastal State bureaucracies. ${ }^{103}$

\section{Arctic Scientific Agreement}

At the Arctic Council's Fairbanks Ministerial in May 2017, the eight Arctic coastal States (Canada, Denmark, Finland, Iceland, Norway, Russian Federation, Sweden and the United States) signed an agreement on enhancing international Arctic scientific cooperation. ${ }^{104}$ The purpose of the agreement is to enhance cooperation in scientific activities in areas where a Party exercises sovereignty, sovereign rights or jurisdiction, including land and internal waters and adjacent territorial sea, EEZ and continental shelf, and areas beyond national jurisdiction in the high seas north of $62^{\circ} \mathrm{N}$, in order to increase effectiveness and efficiency in the development of scientific knowledge about the Arctic.

By its terms, the Agreement is similar to the 2011 Arctic search and rescue agreement. ${ }^{105}$ Although legally binding, the obligations are merely to "facilitate," defined in the agreement as "pursuing all necessary procedures, including giving timely consideration and making decisions as expeditiously

safe to use diplomatic channels. Soons, supra note 5, at 193. The MSR Revised Guide concurs. UN, MSR Revised Guide, supra note 12, at 39, para. 139.

102 To avoid problems the UN MSR Guide recommends also sending a copy directly to the coastal State scientists involved. UN, MSR Guide, supra note 12, at 19, para. 90; this advice is not repeated in the MSR Revised Guide. The Guide also recommends the researching State expressly inform the coastal State involved, after final results and conclusions of a research project have been provided to it, that all obligations related to a specific research project have in its opinion been fulfilled, to avoid invocation of Article 246(5) by the coastal State to withhold consent to future projects because of outstanding obligations to it from a prior research project. UN, MSR Guide, supra note 12, at 20, para. 99; UN, $M S R$ Revised Guide, supra note 12, at 47, para. 178.

103 The UN MSR Guide points out the need for the coastal State to have a single office to process applications for consent and be able to coordinate the request among the relevant government agencies. UN, MSR Guide, at 9, paras. 42, 43, 46; UN, MSR Revised Guide, supra note 12, at 41, para. 147 .

104 Agreement on Enhancing International Arctic Scientific Cooperation, with appendices, 11 May 2017 (entered into force May 23, 2018), TIAS 18-523, available at https://www.state .gov/e/oes/rls/other/2017/2708og.htm.

105 Agreement on Aeronautical Search and Rescue in the Arctic, signed at Nuuk 12 May 2011 (entered into force 19 January 2013), TIAS 13-119, available at https://www.state.gov/documents/organization/205770.pdf. 
as possible." Settlement of disputes is "through direct negotiations." Cooperation with non-Parties is at the Parties discretion.

The agreement entered into force for five years, and automatically renews for further periods of five years. ${ }^{106}$

\section{Value of the LOS Convention Today for MSR}

The foregoing assessment naturally casts doubt on the value today of the LOS Convention to the marine scientific research community. That need not be the case because the Convention is approaching universal acceptance. The Convention is now in force for 167 States and the EC. ${ }^{107}$

President Clinton submitted the Convention to the Senate for advice and consent in 1994. Regarding MSR, the President's Letter of Transmittal stated: "In light of the essential role of marine scientific research in understanding and managing the oceans, the Convention sets forth criteria and procedures to promote access to marine areas, including coastal waters, for research activities."108 The Secretary of State's Report expanded on the importance of the Convention to MSR:

The essential role of marine scientific research in understanding and managing the oceans is also secured. The Convention affirms the right of all States to conduct marine scientific research and sets forth obligations to promote and cooperate in such research. It confirms the rights of coastal States to require consent for such research undertaken in marine areas under their jurisdiction. These rights are balanced by specific criteria to ensure that coastal States exercise the consent authority in a predictable and reasonable fashion to promote maximum access for research activities. ${ }^{109}$

In his 2003 testimony on the Convention before the Senate Foreign Relations Committee, Legal Adviser Taft said:

106 Agreement on Enhancing International Arctic Scientific Cooperation, supra note 104.

107 See, Chronological lists of ratification, available at http://www.un.org/Depts/los/refer ence_files/chronological_lists_of_ratifications.htm\#The\%2oUnited\%2oNations $\% 20$ Convention\%20on\%2othe\%2oLaw\%20of\%2othe\%20Sea.

108 Sen. Treaty Doc. 103-39, supra note 7, at IV.

109 Ibid., at VII; II Digest 1991-1999, at 1559-156o. See further Davies, supra note 5, at 214-215, 224-225. See also Stevenson and Oxman, The Future of the United Nations Convention on the Law of the Sea, 88 American Journal of International LaW 488, 498 (1994). 
The essential role of marine scientific research in understanding and managing the oceans is also secured. The Convention affirms the right of all States to conduct marine scientific research and sets forth obligations to promote and cooperate in such research. It confirms the right of coastal States to require consent for such research undertaken in marine areas under their jurisdiction. These rights are balanced by specific criteria to ensure that coastal States exercise the consent authority in a predictable and reasonable fashion to promote maximum access for research activities. More U.S. scientists conduct marine scientific research in foreign waters than scientists from almost all other countries combined. ${ }^{110}$

The 2004 and 2007 US Senate Executive Reports state regarding MSR:

Part XIII of the Convention recognizes the critical role of marine scientific research in understanding oceanic processes and in informed decision-making about uses of the oceans. Following a maritime zone approach, it provides coastal States with greater rights to regulate marine scientific research in their territorial seas than in the EEZ and on the continental shelf. All States have the right to conduct such research freely in high seas areas. Part XIII also provides for international cooperation to promote marine scientific research. ${ }^{111}$

So how can those coastal States be convinced to accept and carry out their new duties? More than a decade's experience before the Convention entered into force suggested little hope for doing so outside the Convention regime. However, in at least three ways the Convention helps make real the balance of interests reflected in the Convention's terms.

First, States party to the Convention are legally bound by their treaty relationships to comply with the Convention's provisions, which by their nature are more explicit than customary law.

Second, US accession to the Convention would finally place it on a level playing field with other countries. Coastal States would no longer have the excuse that they were bound by the Convention and the United States was nota significant political improvement.

Third, the Convention provides a scheme for resolving MSR disputes with coastal States. This, in and of itself, is an improvement over the present situation.

1102003 Digest, at 718.

111 Quoted in RoAch And Smith (3rd ed.), supra note 1, Appendix 9. 
Further, the dispute settlement regime, discussed next, is a major accomplishment. Indeed, it may provide the only way to restrain-and roll back-excessive coastal State constraints on the conduct of MSR.

\section{MSR Dispute Settlement Regime}

With regard to MSR, the Convention provides that "disputes concerning the interpretation or application of the provisions of this Convention with regard to marine scientific research shall be settled" by the compulsory dispute settlement procedures (CDS). ${ }^{112}$ The Convention also provides that

[a] dispute arising from an allegation by the researching State that with respect to a specific project the coastal State is not exercising its rights under articles 246 and 253 in a manner compatible with this Convention shall be submitted, at the request of either party, to [compulsory nonbinding] conciliation under Annex v, Section 2, provided that the conciliation commission shall not call in question the exercise by the coastal State of its discretion to designate specific areas as referred to in article 246 , paragraph 6 , or of its discretion to withhold consent in accordance with article 246 , paragraph $5 \cdot{ }^{113}$

\section{$1.1 \quad$ Exemptions from CDS}

Article 297(2)(a) carves out two substantial exceptions:

- the exercise by the coastal State of a right or discretion under Article 246 concerning MSR in the EEZ and on the continental shelf; and

- a decision by the coastal State to order suspension or cessation of a research project in accordance with Article 253, because the research activities are not being conducted in accordance with the information communicated to the coastal State under which the consent was based; or the State fails to comply with the conditions established by the State under Article 249 regarding participation, receipt of preliminary results, access to all the data and samples derived from the research, assessment of that data when requested by the coastal State, ensuring international availability of the research results, informing the coastal State immediately of any major changes in the research program, or removal of the scientific research installations or equipment once the research is completed.

MSR exempted from CDS thus includes the following:

112 Arts. 264 and 297(2)(a), LOs Convention.

113 Art. 297(2)(b), Los Convention. 
- the general right to regulate, authorize and conduct MSR in the EEZ or on the continental shelf, ${ }^{114}$ and

- the discretion to withhold consent for MSR in its EEZ or on the continental shelf if that project:

(a) is of direct significance for the exploration and exploitation of natural resources, whether living or non-living. However, Article 246(6) precludes a coastal State from exercising its discretion to withhold consent if the project is to be undertaken on the continental shelf beyond 200 miles, and outside specific areas the coastal State has at any time publicly designated as "areas in which exploitation or detailed exploratory operations focused on those areas" are occurring or will occur within a reasonable period of time;

(b) involves drilling into the continental shelf, the use of explosives or the introduction of harmful substances into the marine environment;

(c) involves the construction, operation or use of artificial islands, installations and structures for economic purposes, and installations and structures which may interfere with the exercise of the rights of the coastal State in the EEZ or on the continental shelf; or

(d) contains inaccurate information communicated to the coastal State, or if the researching State has outstanding obligations to the coastal State from a prior research project.

1.2

Interim Measures

Two other provisions favor the coastal State:

- Article 265, Interim Measures, provides that pending settlement of a dispute, authorized MSR will not begin or continue "without the express consent of the coastal State concerned."

- Further, the provisions of Article 292 authorizing a tribunal or court to order the prompt release of vessels and crews applies by its terms only to detentions for fishing and pollution violations. ${ }^{115}$ Thus there is no guaranteed right of prompt release if a foreign research vessel were detained by the coastal State for violating its MSR laws and regulations.

1.3 Opting Out of CDs for MSR

Article 264 provides that "disputes concerning the interpretation or application of the provisions of [the LOS] Convention with regard to marine scientific

114 Art. 246(1), Los Convention.

115 See Arts. 73(2), 220(7) and 226(1)(b), Los Convention.; cf. Art. 27(3), Los Convention. 
research shall be settled" in accordance with the sections on "compulsory procedures entailing binding decisions" and the limitations and exceptions thereon, set out in Part XV, Settlement of Disputes, Parts 2 [Articles 286-296] and 3 [Articles 297-299], respectively.

For parties to the LOS Convention, Article 286 provides that any dispute concerning the interpretation or application of the Convention shall, where no settlement has been reached by recourse to the general provisions in Section 1 , Articles 279-285, of Part XV on the Settlement of Disputes, be submitted at the request of any party to the dispute to the court or tribunal having jurisdiction under Section 2, Compulsory Procedures Entailing Binding Decisions. There is an exception to this provision pertaining to certain law enforcement activities.

Article 298(1)(b) permits a State, when signing, ratifying or acceding to the Convention or at any time thereafter, to declare in writing that it does not accept the procedures in Section 2 with respect to "disputes concerning law enforcement activities in regard to the exercise of sovereign rights or jurisdiction excluded from the jurisdiction of a court or tribunal under Article 297, paragraph 2 or 3 ". Article 297(3) relates to fishing. Article 297(2) provides regarding MSR:

2. (a) Disputes concerning the interpretation or application of the provisions of this Convention with regard to marine scientific research shall be settled in accordance with Section 2, except that the coastal State shall not be obliged to accept the submission to such settlement of any dispute arising out of:

(i) the exercise by the coastal State of a right or discretion in accordance with article 246; or

(ii) a decision by the coastal State to order suspension or cessation of a research project in accordance with article 253 .

(b) A dispute arising from an allegation by the researching State that with respect to a specific project the coastal State is not exercising its rights under articles 246 and 253 in a manner compatible with this Convention shall be submitted, at the request of either party, to conciliation under Annex v, Section 2, provided that the conciliation commission shall not call in question the exercise by the coastal State of its discretion to designate specific areas as referred to in article 246 , paragraph 6 , or of its discretion to withhold consent in accordance with article 246 , paragraph 5 .

Thus the Convention provides that all disputes regarding MSR are subject to compulsory binding dispute resolution except those disputes regarding the coastal State's (a) discretion to grant or deny MSR applications in its EEZ or on its continental shelf, and (b) decision to order suspension of a research 
project. However, the situations in these two exceptions are subject to compulsory non-binding conciliation.

As of November 2017, the following 17 States have exercised this right under article 298(1)(b): Belarus, Cabo Verde, Canada, Chile, China, Ecuador, Egypt, France, Greece, Mexico, Portugal, Republic of Korea, Russia, Thailand, Tunisia, United Kingdom and Uruguay. ${ }^{116}$ Upon accession, the United States intends to exercise this option. ${ }^{117}$

\subsection{Remedies for Improper Exercise of Discretion}

What aspects of MSR then are subject to dispute resolution? Two important coastal State duties come to mind: (1) the duty of the coastal State to grant consent, in normal circumstances, for MSR projects in the EEZ or on the continental shelf; and (2) the duty to establish rules and procedures ensuring that such consent will not be delayed or denied unreasonably. Although these may not appear to be that significant, it seems that the very existence of these areas should provide the researching State leverage over the coastal State that is not implementing the MSR regime consistent with the terms of the Convention.

The United States now has very little leverage over recalcitrant coastal States, and there is little incentive for those States to change their laws, regulations or procedures. The mere fact that if the United States were party their non-compliance can be brought to compulsory dispute settlement can only be an improvement in the present situation, and should lead to greater conformity with the MSR regime in the Convention.

Thus, US accession to the LOS Convention would provide it the opportunity to use the CDS procedures, an opportunity not available while the United States remains outside the treaty regime.

Finally, US accession to the Convention would enable the United States to consider establishing a Freedom of MSR Program analogous to the NSCdirected State-Defense Freedom of Navigation Program that since 1979 has helped conform state practice to the navigational provisions of the Convention. ${ }^{118}$ Similar results should be sought for MSR.

\section{Conclusions}

This article has demonstrated that not all methods of collection of data about the oceans are marine scientific research regulated by Part XIII of the Law of

\footnotetext{
116 UN, Multilateral Treaties Deposited, supra note 82.

117 US Commentary, supra note 7, at 87.

118 See RoAch AND Smith (3rd ed.), supra note 1, Chapter 1.
} 
the Sea Convention. The means of data collection are often the same, and may appear indistinguishable from MSR. The data collected may be the same or different. The parameters collected, their intended use, and the detailed controls on foreign MSR in the EEZ distinguish MSR from surveys, operational oceanography, exploration and exploitation of resources, and monitoring and environmental assessment. ${ }^{119}$

The article has also demonstrated that proposals that all forms of marine data collection should be under coastal State control ${ }^{120}$ would deprive the people of all nations of the benefits of free and open access to data that enhance safety and environmental protection.

While the lack of agreed definitions of the various methods for marine data collection has resulted in differences of views on the legal regimes governing them, this article has sought to provide clarification and further understanding.

119 See the discussion in ibid., at 82-83 and the text preceding, supra note 5 .

120 See, e.g., Julia Xue, Marine Scientific Research and Hydrographic Surveys in the EEzs: Closing up the Legal Loopholes?, in NORDQUisT, КоH AND MOORE, supra note 28, at 209-225; and Sam Bateman, Hydrographic Surveying in the Exclusive Economic Zones - Is it Marine Scientific Research?, in NORDQUist, KoH AND MOORE, supra note 28, at 105-131. 